\title{
Effect of water quality and season on the population dynamics of Cabomba caroliniana in subtropical Queensland, Australia
}

\author{
Tobias O. Bickel ${ }^{\mathrm{a}}$, Shon S. Schooler ${ }^{\mathrm{b}, *}$ \\ a Invasive Plant Science, Department of Agriculture, Fisheries and Forestry, PO Box 267, Brisbane, QLD, 4102, Australia \\ b CSIRO Ecosystem Sciences, Brisbane, PO Box 2583, QLD, 4001, Australia
}

\section{A R T I C L E I N F O}

\section{Article history:}

Received 14 April 2014

Received in revised form 12 February 2015

Accepted 13 February 2015

Available online 17 February 2015

\section{Keywords:}

Population fluctuation

Invasive plant

Submerged macrophyte

Depth

Seasonality

Fanwort

\begin{abstract}
A B S T R A C T
Cabomba caroliniana is a submersed aquatic macrophyte that originates from the Americas and is currently invading temperate, subtropical, and tropical freshwater habitats around the world. Despite being a nuisance in many countries, little is known about its ecology. We monitored C. caroliniana populations in three reservoirs in subtropical Queensland, Australia, over 5.5 years. Although biomass, stem length, and plant density of the $C$. caroliniana stands fluctuated over time, they did not exhibit clear seasonal patterns. Water depth was the most important environmental factor explaining $C$. caroliniana abundance. Plant biomass was greatest at depths from 2-4 m and rooted plants were not found beyond $5 \mathrm{~m}$. Plant density was greatest in shallow water and decreased with depth, most likely as a function of decreasing light and increasing physical stress. We tested the effect of a range of water physico-chemical parameters. The concentration of phosphorus in the water column was the variable that explained most of the variation in C. caroliniana population parameters. We found that in subtropical Australia, C. caroliniana abundance does not appear to be affected by seasonal conditions but is influenced by other environmental variables such as water depth and nutrient loading. Therefore, further spread will more likely be governed by local habitat rather than climatic conditions.
\end{abstract}

Crown Copyright @ 2015 Published by Elsevier B.V. All rights reserved.

\section{Introduction}

Cabomba caroliniana A. Gray (Cabombaceae; fanwort, cabomba) is a fast-growing submerged aquatic macrophyte that originates from South America and the southeastern United States (Ørgaard, 1991). C. caroliniana is a popular aquarium species and was introduced to aquatic ecosystems worldwide through disposal of aquarium material and escape from culture. Currently C. caroliniana is naturalized in the United States, Canada, Greece, Japan, Malaysia, the Netherlands, Australia, and China (Ørgaard, 1991; Oki, 1992; Les and Mehrhoff, 1999; Zhang et al., 2003; Wilson et al., 2007; Matthews et al., 2013). Once introduced, C. caroliniana causes a range of ecological (Mackey and Swarbrick, 1997; Hogsden et al., 2007; Wilson et al., 2007) and socio-economic impacts (Mackey and Swarbrick, 1997; Dugdale et al., 2013).

Cabomba caroliniana was first recorded in Australia in 1967 and is now naturalized in large parts of the country with established

\footnotetext{
* Corresponding author. Current address: Lake Superior National Estuarine Research Reserve, 14 Marina Dr, Superior, WI, 54880, USA. Tel.: +11 1715392 3141; fax: +11 17153923144

E-mail address: sschoole@uwsuper.edu (S.S. Schooler).
}

populations found from temperate (Victoria, New South Wales) to subtropical (southeast Queensland) and tropical climates (Northern Territory, northern Queensland) (Mackey, 1996; Mackey and Swarbrick, 1997; Ensby, 2004; Schooler and Julien, 2006). Although cultivation and sale of $C$. caroliniana is now prohibited, the plant is increasing its naturalized range and could potentially establish in large parts of Australia with suitable habitat. In Australia, once introduced C. caroliniana is difficult to manage due to limited availability of effective control options (Anderson and Diatloff, 1999; Schooler and Julien, 2006; Hogsden et al., 2007). Hence, prevention of further spread is paramount for effective management.

Even though $C$. caroliniana is considered a pest in many countries, little is known about its ecology and population dynamics. While a significant part of the introduced range of $C$. caroliniana lies in subtropical climates (e.g. the majority of $C$. caroliniana infestations in Australia are found in the subtropical climate zone), most research within its introduced range covers temperate climates. Because of the large differences between temperate and subtropical aquatic systems it is not straightforward to extrapolate research findings from temperate regions into subtropical systems affected by $C$. caroliniana. In temperate regions macrophytes tend to exhibit seasonal variations in standing crop biomass. Plant populations usually decline during colder months and plants overwinter 
Table 1

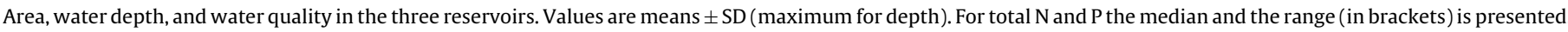
Data were collected by the authors between 2005 and 2008 unless indicated otherwise.

\begin{tabular}{|c|c|c|c|c|c|c|c|c|}
\hline & Area (ha) & Depth (m) & $\begin{array}{l}\text { Temperature } \\
\left({ }^{\circ} \mathrm{C}\right)\end{array}$ & $\begin{array}{l}\text { Conductivity } \\
\left(\mu \mathrm{cm}^{-1}\right)\end{array}$ & $\mathrm{pH}$ & $\begin{array}{l}\text { Secchi depth } \\
(\mathrm{m})\end{array}$ & Total N $\left(\mathrm{mg} \mathrm{L}^{-1}\right)$ & Total P $\left(\mathrm{mg} \mathrm{L}^{-1}\right)$ \\
\hline Ewen Maddock Dam & 370 & $7.7 \pm 1.5(>7 \mathrm{~m})^{*}$ & $21.6 \pm 4.4^{\#}$ & $126 \pm 111^{\#}$ & $6.8 \pm 0.3^{\#}$ & $1.7 \pm 0.4$ & $0.51(0.28-12.51)^{\#}$ & $0.02(0.01-3.44)^{\#}$ \\
\hline Lake Macdonald & 260 & $6.5 \pm 0.5(7.1)^{*}$ & $23.2 \pm 2.0^{\#}$ & $106 \pm 21^{\#}$ & $6.7 \pm 0.2^{\#}$ & $1.1 \pm 0.2$ & $0.67(0.00-2.10)^{\#}$ & $0.02(0.00-0.12)^{\#}$ \\
\hline Seibs Dam & 3.5 & $(4.0)$ & $23.9 \pm 3.3$ & $91 \pm 5$ & $6.5 \pm 0.7$ & $0.8 \pm 0.1$ & $2.74(2.46-3.03)$ & $0.44(0.22-0.60)$ \\
\hline
\end{tabular}

Data provided by SEQwater.

\# Data provided by SEQwater, averages from 2005-2008 monthly monitoring.

in the seedbank or as vegetative propagules. In tropical regions, aquatic plant populations are largely shaped by water level variations induced by rainfall patterns. Cabomba species show similar variations in growth and biomass depending on geographic location and climate. In the monsoonal climate of Malaysia, Cabomba furcata Schultes and Schultes f. (1830) exhibited pronounced seasonal population variations related to high-flow monsoonal rain events (Sharip et al., 2012). In tropical southern Brazil, C. furcata populations persist throughout the year, but even though there are no marked high-flow events, there are seasonal fluctuations in productivity that are related to light intensity and availability of organic carbon (Camargo et al., 2006).

In temperate climates of the continental USA (New Jersey) and Canada there is a seasonal cycle of $C$. caroliniana populations. In spring, $C$. caroliniana grows rapidly toward the water surface and can fill the entire water column (Wilson et al., 2007). Peak biomass of $110-240 \mathrm{~g}$ dry mass $\mathrm{m}^{-2}$ is reached in the northern hemisphere in late summer to early autumn (August-October) (Noel, 2005; Wilson et al., 2007). Toward the end of the growing season $C$. caroliniana plants fragment, and in spring new shoots emerge from fragments and turion-like structures (Riemer and Ilnicki, 1968; Wilson et al., 2007). While there is currently no information on C. caroliniana growth in subtropical climates, it is reasonable to expect that $C$. caroliniana would exhibit seasonal variation in population size similar to those found in temperate climates. However, as temperature fluctuations are less pronounced in subtropical than in temperate aquatic ecosystems, variation in C. caroliniana populations might be less pronounced than in temperate climates.

Other environmental factors that are likely to affect subtropical C. caroliniana populations are availability of light and nutrients. Even though $C$. caroliniana is a shade tolerant species and can persist in turbid water bodies (Zhang et al., 2003; Lyon and Eastman, 2006), C. caroliniana growth is influenced by water turbidity and subsequent light extinction (Schooler, 2008; van Valkenburg et al., 2011). C. caroliniana is usually found in shallow water to $3 \mathrm{~m}$, but can grow to $10 \mathrm{~m}$ depths in some habitats (Ørgaard, 1991; Mackey and Swarbrick, 1997; Hogsden et al., 2007). In a turbid lake in temperate USA (MA), C. caroliniana abundance varied with water depth, with abundance being highest in relative shallow depths (0.5-1.5 m) (Lyon and Eastman, 2006). In its introduced range $C$. caroliniana is able to adapt to a wide range of temperature, water quality and substrate conditions and its distribution is more likely to be determined by dispersal than habitat quality (Sheldon, 1994; Zhang et al., 2003).

Submersed macrophytes such as $C$. caroliniana can satisfy their nutrient requirements either through uptake from the substrate or the water column. Cabomba caroliniana thrives in freshwater systems with a wide range of nutrient concentrations, from oligotrophic to eutrophic systems (Oki, 1992; Wilson et al., 2007; van Valkenburg et al., 2011). Elevated nutrient concentrations in the substrate can increase its growth performance (Bickel, 2012). However, we do not know if $C$. caroliniana can be nutrient limited in natural systems or benefits from anthropogenic eutrophication. This lack of knowledge is critical as it prevents projecting future problems with $C$. caroliniana incursions in the light of increasing anthropogenic eutrophication.

In this paper we present survey results of $C$. caroliniana populations from three infested lakes in South-east Queensland, Australia. We hypothesized that: (1) environmental factors (depth, nutrients and water clarity) affect $C$. caroliniana populations and (2) C. caroliniana undergoes seasonal variations in biomass similar to those found in other climates. The knowledge of $C$. caroliniana ecology and population variability in subtropical climates is important to tailor successful management scenarios integrating herbicide and future biological control options (Schooler et al., 2012).

\section{Methods}

\subsection{Fieldwork}

Cabomba caroliniana populations were sampled seasonally (approximately every 3-6 months) over 5.5 years from $14 \mathrm{Sept}$ 2004 to 16 March 2010 at three reservoirs in southeast Queensland. The three sites sampled were: Lake Macdonald $\left(26.38549^{\circ} \mathrm{S}\right.$, $\left.152.92905^{\circ} \mathrm{E}\right)$, Ewen Maddock $\operatorname{Dam}\left(26.79658^{\circ} \mathrm{S}, 152.99017^{\circ} \mathrm{E}\right)$, and Seibs Dam $\left(26.49354^{\circ} \mathrm{S}, 152.97256^{\circ} \mathrm{E}\right)$. The three lakes were all artificially impounded reservoirs that had similar water chemistry with low conductivity and slightly acidic water, but differed in area, depth, and nutrient concentration (Table 1). Lake Macdonald and Ewen Maddock Dam were potable water reservoirs and Seibs Dam was an impounded farm dam that was built for livestock watering, but was not in use during the course of this study (no water was extracted and no livestock were present). Water quality data of Lake Macdonald and Ewen Maddock Dam used in this study was supplied by SEQwater (www.seqwater.com.au), the water supplier of South East Queensland including the greater Brisbane area. The water quality data was collected by SEQwater during their routine monthly monitoring of water quality in these reservoirs (eleven monitoring sites in Ewen Maddock Dam and five sites in Lake MacDonald). Water quality data in Seibs Dam was collected by the authors over the course of the study, but this data set was too small to use in a linear regression (see below).

In each lake we selected one focal site for long-term sampling. Each site was randomly selected from a set of pre-defined areas that were accessible and had low potential for management disturbance based on discussions with reservoir managers. Each site was defined as a transect $60 \mathrm{~m}$ in length along the shoreline. Permanent stakes were placed at each end of the transect. For each sampling event three points were randomly chosen along the shoreline transect. From each point we ran a transect perpendicular to the shore out into the reservoir and sampled $C$. caroliniana at $1 \mathrm{~m}$ depth increments to maximum depth at the site. Sampling was destructive so stakes were placed at the start of each depth transect to prevent sampling the same locations during future sampling events.

Sampling was staged from a boat starting from the shoreline and moving to open water. A weighted measuring tape was used to determine depth. When the desired depth was found, a diver using SCUBA followed the line to the bottom and inserted a three-sided quadrat frame $\left(0.25 \mathrm{~m}^{2}\right)$ such that the weighed line was positioned 
Table 2

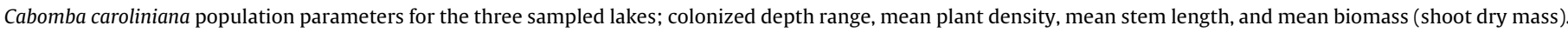
All variables \pm SD and range in brackets.

\begin{tabular}{|c|c|c|c|c|}
\hline & Depth $(\mathrm{m})$ & Shoot dry mass $\left(\mathrm{g} \mathrm{m}^{-2}\right)$ & Plant density $\left(\mathrm{N} \mathrm{m}^{-2}\right)$ & Stem length $(\mathrm{cm})$ \\
\hline Ewen Maddock Dam & $(1-5)$ & $126 \pm 96(0-472)$ & $18 \pm 14(0-88)$ & $259 \pm 120(20-710)$ \\
\hline Lake Macdonald & $(1-5)$ & $106 \pm 109(0-671)$ & $15 \pm 15(0-84)$ & $226 \pm 98(41-455)$ \\
\hline Seibs Dam & $(1-3)$ & $196 \pm 152(0-738)$ & $22 \pm 19(0-116)$ & $219 \pm 89(33-384)$ \\
\hline
\end{tabular}

at the diver's left corner. Therefore, sample area was determined at the substrate level (not area at the water surface). The three reservoir sites had silty substrates, which allowed easy removal of plants by pulling from the base (although probably some of the fine root mass was lost during removal and washing). All plants in the plot were collected by pulling roots out of the sediment from plant base, washing at the surface, placing in labeled plastic bags and into coolers, and taken to CSIRO Long Pocket Labs, Indooroopilly, QLD. Samples were refrigerated until measurements were taken (within 5 days of collection).

Measurements included plant stem length, plant density, and dry weight. Each plant was removed from the plastic bag, stretched to full length on a table, and length of longest stem (from stem base) was recorded. Number of entire plants (with a plant defined as all shoots from one common plant base, irrespective of the number of shoots) was counted for each plot. Then roots were cut off at the base and all stems for each plot were placed in a labeled paper bag, dried at $65^{\circ} \mathrm{C}$ to constant weight in a drying oven, and weighed to the nearest $0.01 \mathrm{~g}$. Biomass did not include root weight as we could not be sure that all root material was collected using the methods described above.

In 2006, C. caroliniana samples were collected from each reservoir to determine $\mathrm{N}: \mathrm{P}$ tissue content (20 samples in total). Samples were dried at $30^{\circ} \mathrm{C}$ and subsequently ground in a tissue grinder. Nitrogen content was determined by combustion using a LECO CNS 2000 combustion analyzer set at $1100^{\circ} \mathrm{C}$. Phosphorus tissue content was obtained by ICPOES following digestion with 5:1 nitric:perchloric acid.

\subsection{Statistical analysis}

To avoid pseudo-replication averages of the three plots (subsamples) were calculated and used as replicates (one value per depth per sampling event for each lake) in the statistical analysis. Sampling was destructive and each transect represented a new sample area so repeated measures ANOVA was not used to test for differences in temporal patterns. Instead, a three-way ANOVA (depth $\times$ season $\times$ reservoir) was used to test for significant effects of depth, season and site on C. caroliniana populations.

Linear regression was used to examine possible relationships between seasonal averages of water physico-chemical variables (e.g. nutrient concentration; see Table 4 for full list of variables) and seasonal averages of $C$. caroliniana population parameters. Physicochemical variables were only available on a seasonal basis for Ewen Maddock Dam and Lake Macdonald and the data of these two populations were pooled for this analysis. Data were square root transformed when necessary to meet the assumptions of parametric tests. Statistical analyzes were carried out in R 3.0.1 (R Core Team, 2013).

\section{Results}

\subsection{Spatio-temporal variation in C. caroliniana population dynamics}

Cabomba caroliniana was present from the shoreline to $5 \mathrm{~m}$ depth in Ewen Maddock Dam and Lake Macdonald. In Seibs Dam C. caroliniana was present to a depth of $3 \mathrm{~m}$. The results of the 3-way ANOVA indicated that mean biomass (shoot dry mass, Table 2) differed significantly between sites and depth (significant site $\times$ depth interaction: Table 3 ) while there was no significant seasonal interaction ( $p>0.05$, Table 3$)$. For plant density and stem length, the statistical relationships were more complex, as there were also significant interactions with season (Table 3). For all three C. caroliniana population parameters, depth and site explained the majority of the observed variability in the data while season only contributed little to the plant density and stem length 3-way ANOVA models.

Cabomba caroliniana biomass differed significantly between the three sites (Tukey HSD: $p<0.02$ ) with the highest mean dry mass found in Seibs Dam followed by Ewen Maddock Dam and Lake Macdonald (Table 2). Seibs Dam also had the highest $C$. caroliniana density, but the difference was only significant compared to Lake Macdonald (Tukey HSD: $p<0.00001$ ). Stem length was significantly lower in Seibs Dam compared to Lake Macdonald (Table 2, Tukey HSD: $p<0.0001)$ but was similar between Seibs Dam and Ewen Maddock Dam (Tukey HSD: $p=0.60$ ).

The $C$. caroliniana populations displayed considerable temporal variation in the three lakes (Fig. 1a-c). However, there was no clear seasonal pattern; i.e. biomass maxima occurred in random seasons. Because of the high temporal variability of the $C$. caroliniana stands, there was no statistical difference in biomass between seasons (3-way ANOVA: Table 3). However, plant density and stem length differed significantly between seasons (3-way ANOVA: Table 3). Plant height differed significantly between spring and autumn (Tukey HSD: $p=0.0245$ ) and between spring and summer (Tukey HSD: $p=0.0453$ ) with highest average biomass occurring in spring. Plant density was significantly higher in spring compared to autumn (Tukey HSD: $p=0.044$ ).

Cabomba caroliniana biomass, plant density, and stem length differed significantly between the sampled depths in all three habitats (3-way ANOVA: Table 3). Highest C. caroliniana biomass (shoot dry

Table 3

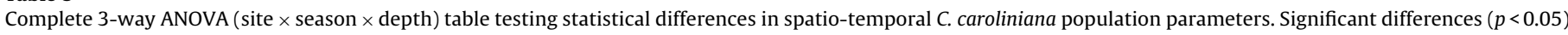
are indicated in bold.

\begin{tabular}{|c|c|c|c|c|}
\hline & $\mathrm{DF}$ & Shoot dry mass & Plant density & Stem length \\
\hline Site & 2 & $F=25.04, \boldsymbol{p}<0.0001$ & $F=18.43, \boldsymbol{p}<0.0001$ & $F=19.7, \boldsymbol{p}<0.0001$ \\
\hline Season & 3 & $F=1.73, p=0.16$ & $F=2.96, \boldsymbol{p}=\mathbf{0 . 0 3}$ & $F=3.54, \boldsymbol{p}=\mathbf{0 . 0 2}$ \\
\hline Depth & 4 & $F=38.31, \boldsymbol{p}<0.0001$ & $F=104.87, \boldsymbol{p}<0.0001$ & $F=69.56, \boldsymbol{p}<n 0.0001$ \\
\hline Site $\times$ season & 6 & $F=0.88, p=0.51$ & $F=2.23, \boldsymbol{p}=\mathbf{0 . 0 4}$ & $F=1.037, p=0.40$ \\
\hline Site $\times$ depth & 6 & $F=3.50, \boldsymbol{p}=\mathbf{0 . 0 0 2 7}$ & $F=4.87, \boldsymbol{p}=\mathbf{0 . 0 0 0 1}$ & $F=14.98, \boldsymbol{p}<0.0001$ \\
\hline Season $\times$ depth & 12 & $F=0.89, p=0.56$ & $F=0.95, p=0.50$ & $F=1.67, p=0.08$ \\
\hline Site $\times$ season $\times$ depth & 18 & $F=0.85, p=0.63$ & $F=0.36, p=0.99$ & $F=0.83, p=0.67$ \\
\hline
\end{tabular}


Table 4

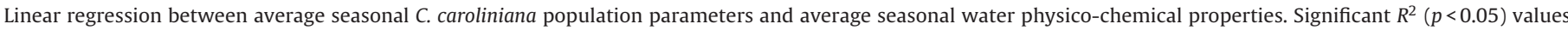
are indicated in bold. The mean $( \pm S D)$ and range of the seasonal water physic-chemical parameters used in the analysis are presented in the last column.

\begin{tabular}{|c|c|c|c|c|}
\hline & Shoot dry mass $R^{2}$ & Plant density $R^{2}$ & Stem length $R^{2}$ & Mean \pm SD (range) \\
\hline Temperature $\left(\mathrm{C}^{\circ}\right)$ & 0.00 & 0.02 & 0.04 & $22.8 \pm 3.1(15.8-28.4)$ \\
\hline Conductivity $\left(\mu \mathrm{Scm}^{-1}\right)$ & 0.01 & 0.01 & 0.19 & $119 \pm 25(65-168)$ \\
\hline $\mathrm{pH}$ & 0.05 & 0.00 & 0.01 & $6.8 \pm 0.2(6.6-7.4)$ \\
\hline Secchi depth (m) & 0.04 & 0.00 & 0.08 & $1.05 \pm 0.17(0.72-1.40)$ \\
\hline Color & 0.01 & 0.07 & 0.01 & $47.9 \pm 11.3(29.8-83.3)$ \\
\hline Turbidity (NTU) & 0.16 & 0.00 & 0.09 & $6.1 \pm 4.2(2.1-18.0)$ \\
\hline Suspended solids ( $\mathrm{mg} \mathrm{L}^{-1}$ ) & 0.08 & 0.11 & 0.08 & $7.3 \pm 7.1(2.2-28.0)$ \\
\hline Dissolved oxygen $\left(\mathrm{mg} \mathrm{L}^{-1}\right)$ & 0.02 & 0.04 & 0.04 & $5.5 \pm 1.2(3.6-7.8)$ \\
\hline Chla $\left(\mathrm{mg} \mathrm{L}^{-1}\right)$ & 0.00 & 0.13 & 0.03 & $9.1 \pm 2.1(5.1-14.1)$ \\
\hline Total $\mathrm{N}\left(\mathrm{mg} \mathrm{L}^{-1}\right)$ & 0.00 & 0.02 & 0.00 & $0.67 \pm 0.20(0.35-1.08)$ \\
\hline Total $\mathrm{P}\left(\mathrm{mg} \mathrm{L}^{-1}\right)$ & 0.20 & 0.43 & 0.19 & $0.04 \pm 0.03(0.00-0.16)$ \\
\hline $\mathrm{NH}_{3}-\mathrm{N}\left(\mathrm{mg} \mathrm{L}^{-1}\right)$ & 0.19 & 0.08 & 0.11 & $0.04 \pm 0.04(0.00-0.16)$ \\
\hline Soluble reactive $\mathrm{P}\left(\mathrm{mg} \mathrm{L}^{-1}\right)$ & 0.08 & 0.17 & 0.22 & $0.01 \pm 0.01(0.00-0.04)$ \\
\hline Total $\mathrm{Mn}\left(\mathrm{mg} \mathrm{L}^{-1}\right)$ & 0.04 & 0.04 & 0.09 & $0.17 \pm 0.16(0.01-0.56)$ \\
\hline
\end{tabular}

mass) was observed in the mid depths from 2-3 $\mathrm{m}$ in Ewen Maddock Dam and Lake Macdonald (Fig. 2) and at $2 \mathrm{~m}$ for Seibs Dam. The highest biomass was recorded at $738 \mathrm{~g} \mathrm{~m}^{-2}$ in Seibs Dam at $3 \mathrm{~m}$ depth (Table 2); the largest samples in Ewen Maddock Dam and Lake Macdonald were recovered at $4 \mathrm{~m}$ depth. Biomass tended to be lower in the $1 \mathrm{~m}$ depth sampling stations than in the mid depths (not significantly different for Ewen Maddock Dam). The lowest biomass was found in the $5 \mathrm{~m}$ depth zone in Ewen Maddock Dam and Lake Macdonald (Seibs Dam did not have C. caroliniana beyond $3 \mathrm{~m}$ ).

Cabomba caroliniana density differed significantly between sampled water depths for all three reservoirs (3-way ANOVA: Table 3). Density was greatest in shallow water $(1-2 \mathrm{~m})$ and decreased with increasing depth (Fig. 2). The greatest number of plants, 116 plants $\mathrm{m}^{-2}$, was sampled in Seibs Dam at $1 \mathrm{~m}$ water depth (Table 2), the maxima in Lake Macdonald and Ewen Maddock Dam occurred in $1 \mathrm{~m}$ depth as well.

Overall, $C$. caroliniana stems grew longer with increasing depth from 1 to $4 \mathrm{~m}$ (Fig. 2). Very long plants still occurred at $5 \mathrm{~m}$ depth in Ewen Maddock Dam but variability was high. Stem length decreased significantly at $5 \mathrm{~m}$ in Lake Macdonald. The plant with the greatest stem length was $7.1 \mathrm{~m}$ and was found growing in $3 \mathrm{~m}$ of water in Ewen Maddock Dam (Table 2). The longest plants grew in $4 \mathrm{~m}$ in Lake Macdonald and $3 \mathrm{~m}$ depth in Seibs Dam.

\subsection{Effect of physico-chemical parameters on C. caroliniana population dynamics}

We performed linear regressions to find potential relationships between seasonal $C$. caroliniana population parameters and water physico-chemical parameters (Table 4). Of the 14 parameters tested, only five (conductivity, turbidity, total $\mathrm{P}, \mathrm{NH}_{3}-\mathrm{N}$ and soluble reactive phosphorus) significantly explained some of the variation of $C$. carolinina populations (Fig. 3 and Table 4), though the relationships were not strong. After removing three outliers (the three largest total $P$ values) from the regression analysis, total phosphorus concentration was the best predictor of $C$. caroliniana populations, in particular plant density $\left(R^{2}=0.43\right.$; Fig. 3$)$. Turbidity seemed to affect $C$. caroliniana shoot dry mass but had no effect on plant density or stem length (Table 4 and Fig. 3) and there was a small effect of conductivity on stem length.
The $C$. caroliniana tissue nutrient content appeared unrelated to the water column nutrient concentration in the respective reservoirs (Tables 1 and 5). While the nitrogen loading in the water column varied considerably in the three habitats (Table 1; total $\mathrm{N}=0.51-2.74 \mathrm{mg} \mathrm{L}^{-1}$ ), nitrogen tissue content differed little (Table 5; N\% dry wt $=2.64-2.89$ ). Similarly, there was no clear pattern between the phosphorus loading of the water column (Table 1 ; total $\mathrm{P}=0.02-0.44 \mathrm{mg} \mathrm{L}^{-1}$ ) and the phosphorus tissue content (Table 5; P\% dry wt $=0.14-0.24$ ). For example, Seibs Dam had a much higher $P$ loading compared to the other two reservoirs, but C. caroliniana tissue samples from Lake Macdonald had the highest $P$ content. The N:P ratios of the $C$. caroliniana tissue samples were similar between Ewen Maddock Dam and Seibs Dam (N:P=20.6 and 18.1), but were lower in Lake Macdonald (Table 5; N:P=12.3).

\section{Discussion}

Cabomba caroliniana populations were highly variable over time and among reservoirs. However, while the biomass, density, and stem length of the $C$. caroliniana plants fluctuated over time, there were no discernible seasonal patterns. One reason for this might be that the climate in Queensland is favorable for C. caroliniana growth year-round and that other external factors affect the extent of $C$. caroliniana stands in the sampled lakes. The water temperatures found in the three lakes fall within the optimum temperature range reported in the literature (Ørgaard, 1991; Mackey and Swarbrick, 1997) throughout the year. The optimum growing conditions regarding temperature and water chemistry also explain the much higher maximum biomass $\left(472-740 \mathrm{~g} \mathrm{~m}^{-2}\right)$ and a similar average biomass (126-196 $\mathrm{g} \mathrm{m}^{-2}$ ) that was measured in these subtropical lakes compared to peak biomass $\left(110-240 \mathrm{~g} \mathrm{~m}^{-2}\right.$ ) observed in temperate Canadian lakes (Noel, 2005; Hogsden et al., 2007). In fact, average biomass in all three of the Queensland lakes were yearround on a similar level compared to the peak biomass attained in the temperate lakes.

The subtropical C. caroliniana populations in Queensland did not exhibit similar seasonal variations as observed in tropical populations of C. furcata in Brazil and Malaysia (Camargo et al., 2006; Sharip et al., 2012). Both of these C. furcata populations occurred in areas with a monsoonal climate and plant biomass varied with monsoonal flow events. The subtropical C. caroliniana populations

Table 5

Mean $\mathrm{N}$ and $\mathrm{P}$ tissue content $\pm \mathrm{SD}$ (with range in brackets) of $C$. caroliniana collected from the three reservoirs in 2006 and the N:P ratio.

\begin{tabular}{|c|c|c|c|}
\hline & $\mathrm{N}(\%$ dry wt) & $\mathrm{P}$ (\% dry wt) & $\mathrm{N}: \mathrm{P}$ \\
\hline Ewen Maddock Dam & $2.69 \pm 0.38(2.07-3.03)$ & $0.14 \pm 0.14(0.07-0.16)$ & $20.6 \pm 4.1(17.0-27.7)$ \\
\hline Lake Macdonald & $2.89 \pm 0.19(2.60-3.11)$ & $0.24 \pm 0.04(0.17-0.28)$ & $12.3 \pm 1.6(10.7-15.8)$ \\
\hline Seibs Dam & $2.64 \pm 0.54(2.07-3.13)$ & $0.15 \pm 0.04(0.11-0.17)$ & $18.1 \pm 1.6(16.4-19.6)$ \\
\hline
\end{tabular}




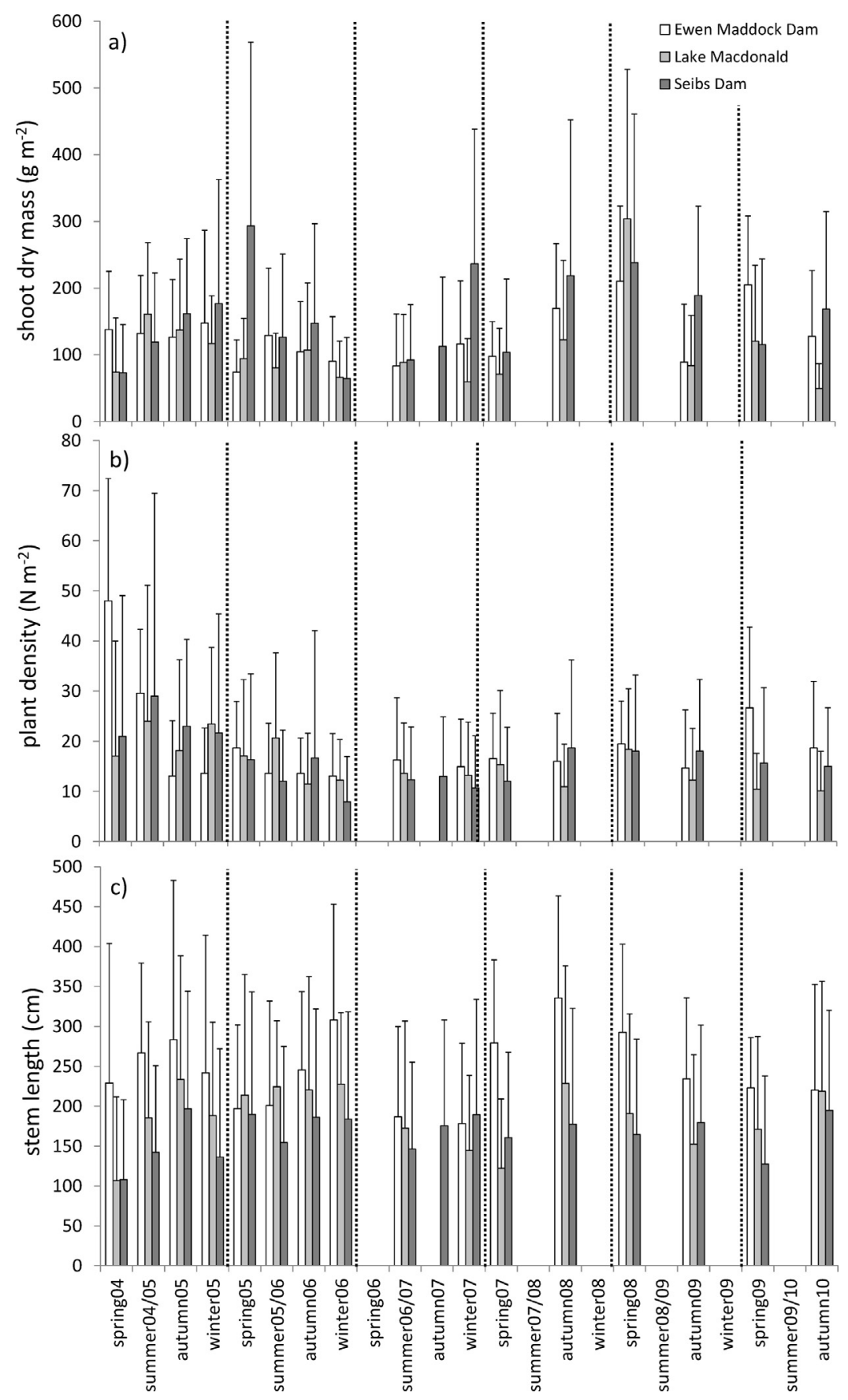

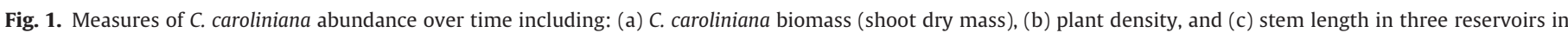

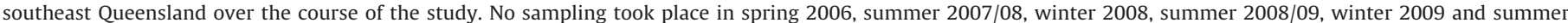
2009/10. Missing bars in autumn 2007 indicate zero values.

in Queensland are situated in a similar monsoonal climate but did not show any seasonal patterns. The reason for this might be the high inter-annual variability of rainfall in Queensland. During the study periods, the climate in Queensland was in a dry cycle and there were no major flooding events. Therefore, the lack of a seasonal pattern that was found in these $C$. caroliniana populations might be the result of the absence of flood events during the survey time period. Also, the studied populations are situated in drinking water reservoirs (Ewen Maddock Dam Lake Macdonald) and a farm dam (Seibs Dam), which likely experience lower fluctuations in water levels as compared to the $C$. furcata populations studied in a natural flood plain environment in Brazil (Camargo et al., 2006). The water level of Ewen Maddock Dam for example fluctuated only by a maximum of $1.4 \mathrm{~m}$ during the study period (data supplied by SEQwater). Also, both studies of $C$. furcata populations were limited to a single seasonal cycle (Camargo et al., 2006; Sharip et al., 2012), while the present survey was conducted over 5.5 years. Therefore, it is possible that the seasonal patterns that were found in the $C$. furcata populations might not occur during all years in these populations.

While there was no clear temporal pattern for the studied $C$. caroliniana populations, there were clear differences in $C$. caroliniana biomass, stem length, and density between the three reservoirs. This can partly be explained by differences in the habitat qualities of the reservoirs. The two deeper reservoirs, Ewen Maddock Dam and Lake Macdonald, allowed stems to grow longer than in Seibs Dam. 

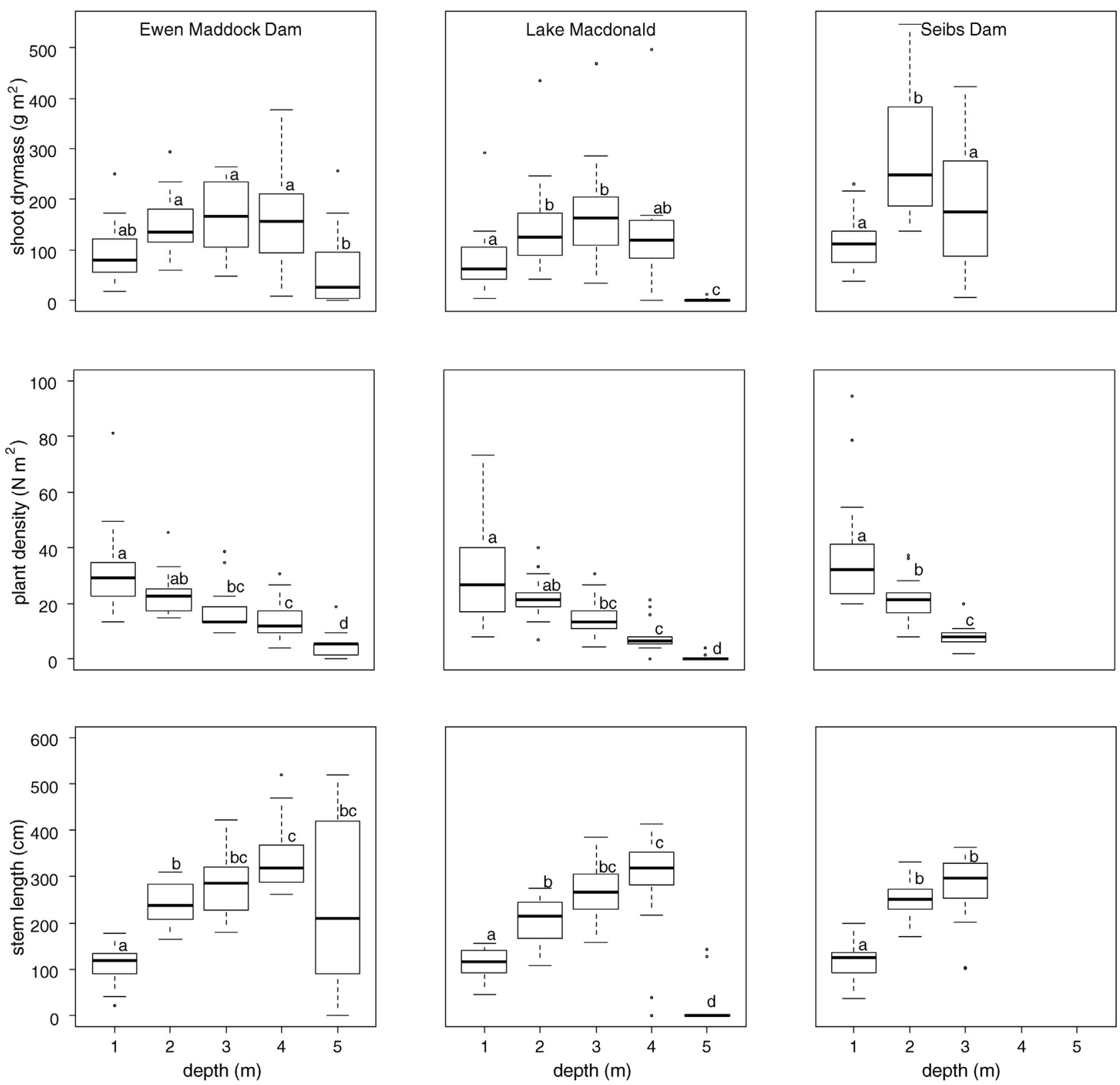

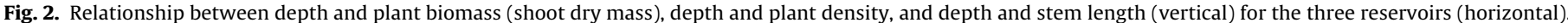
Letters indicate significant differences at the $p<0.05$ level.

Contrary to this, the higher nutrient concentrations could account for the higher $C$. caroliniana biomass encountered in Seibs Dam for example through a more compact and denser growth form. In fact, we found a positive linear relationship between total phosphorus and C. caroliniana growth. The smaller area of Seibs Dam may also result in lower mechanical disturbance on the $C$. caroliniana stems due to the lower effective fetch, therefore allowing $C$. caroliniana to accumulate a higher biomass.

Not surprisingly, water depth was the main environmental variable associated with variation in $C$. caroliniana biomass, density, and stem length. C. caroliniana grew to depths of $5 \mathrm{~m}$ in Ewen Maddock Dam and Lake Macdonald, but biomass was greatest in mid depths of $2-4 \mathrm{~m}$. The higher biomass in the mid depths is possibly the result of the increasing stem length with increasing depth. In deeper water $C$. caroliniana stems elongate to reach the higher light intensities of surface waters, and subsequently standing crop biomass increases with depth. However, in deeper water beyond $4 \mathrm{~m}$ (in Ewen Maddock Dam and Lake Macdonald), C. caroliniana biomass became highly variable. This is most likely a result of a combination of light attenuation and physical stress.

The availability of light for photosynthesis is one of the most important environmental factors regulating aquatic plant growth (Sand-Jensen, 1989; Bornette and Puijalon, 2011) and water clarity frequently shapes species composition in macrophyte communities (Hawes et al., 2003). Due to the reduced light availability in deeper water, depths greater than $4 \mathrm{~m}$ are marginal habitat for C. caroliniana. In Seibs Dam low water clarity is likely responsible for $C$. caroliniana being restricted to less than $4 \mathrm{~m}$ depth (see also: Schooler and Julien, 2006).

Plant density was greatest at shallow depths in all three habitats. This may be due to broken fragments lodging near the shore and then taking root. Plants in water greater than $1 \mathrm{~m}$ depth tended to be solitary with root clumps separated from other plants, whereas plants in less than $1 \mathrm{~m}$ depth tended to have roots that grew together and formed a mat. Shallow habitats also have relatively higher light availability and allow increased plant density, com- 

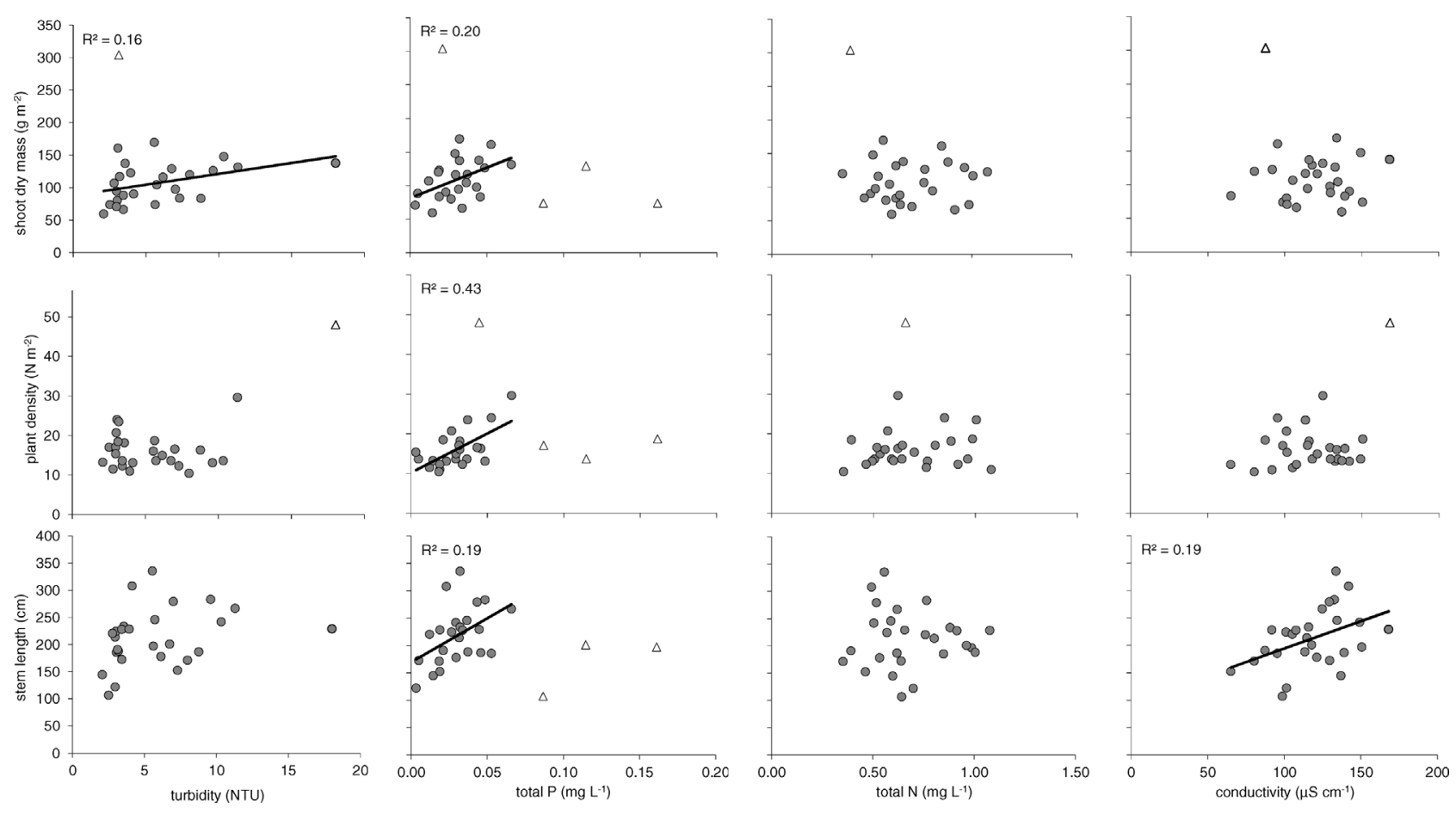

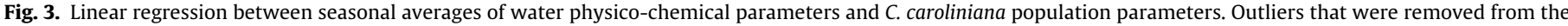
regression analysis are plotted as triangles. Significant $R^{2}(p<0.05)$ values are displayed in the plots.

pared to deeper areas where $C$. caroliniana stands exhibit reduced plant density, but each plant tends to produce more stems with greater stem length in order to maximize light acquisition. C. caroliniana populations in temperate USA (MA) and Canadian lakes exhibit similar patterns in depth distribution as found here, with $C$. caroliniana being limited to comparatively shallow depths, either as a result of high turbidity (Lyon and Eastman, 2006) or because of the more sheltered aspect of shallow bays that allow prolific $C$. caroliniana growth (Hogsden et al., 2007).

When testing for effects of water physico-chemical parameters on C. caroliniana populations, we found few significant relationships and these were not strong. We expected that measures of water transparency (Secchi depth, turbidity and water color) would affect $C$. caroliniana. However, we only found a significant linear relationship between turbidity and shoot dry mass. The lack of a strong effect of water transparency on $C$. caroliniana growth can be explained by a combination of the low light requirements of $C$. caroliniana (Zhang et al., 2003; Lyon and Eastman, 2006), the shallow habitats that were part of this study and the comparatively high water transparency in general; i.e. in the studied systems $C$. caroliniana is not limited by light and therefore we were unable to find any significant relationships. More research is clearly needed to accurately measure the light requirements of $C$. caroliniana in the future. Cabomba caroliniana growth is reduced at a higher $\mathrm{pH}$ (Bickel, 2012Bickel, 2012 Mackey and Swarbrick, 1997; Ørgaard, 1991), therefore we expected to find a relationship between the $\mathrm{pH}$ and C. caroliniana populations. However, we did not find any evidence of such a relationship in this study. The reason for this is most likely that the three reservoirs have a $\mathrm{pH}$ conducive to $C$. caroliniana growth and the sampled $\mathrm{pH}$ range was too narrow to be able to detect a meaningful relationship.

We also anticipated that nutrient concentrations in the water column would influence $C$. caroliniana growth. While nitrogen concentration in the water column did not show any effect on $C$. caroliniana, we found a positive relationship between phosphorus concentrations and $C$. caroliniana population parameters. This would mean that $C$. caroliniana is potentially limited by phosphorus in the studied systems, while nitrogen is not limiting. Considering the concentration of macro-nutrients in the water column, all three of the systems could be described as eutrophic (Table 1 ), with high availability of nitrogen and phosphorus. While macrophytes are commonly able to satisfy their nutrient requirements from the water column (e.g. Madsen and Cedergreen, 2002), there seems to be no consistent relationship between nutrient concentrations in the water column and growth parameters in the literature. Some studies find a lack of relationship between nutrient loading and macrophyte growth (Madsen and Cedergreen, 2002) while other report such a relationship (Wersal and Madsen, 2011; O'Hare et al. 2010). The reason for this might be that the available nutrients satisfy the nutrient requirements for maximum growth and therefore additional nutrients do not result in higher growth rates (Madsen and Cedergreen, 2002).

The tissue nutrient concentrations found in C. caroliniana were similar to those found in other macrophytes (Duarte, 1992; James et al., 2006). However, the water column nutrient concentration in the three reservoirs did not correspond with the nutrient content in C. caroliniana tissue. Again, there are no consistent findings from the literature. Some researchers found a relationship (James et al., 2006), while others did not (Güswell et al., 2003). It has also been suggested that $\mathrm{N}: \mathrm{P}$ ratios might be more indicative of nutrient limitations than nutrient tissue content itself (Güswell and Koerselman, 2002) and that N:P ratios $>20$ indicate a phosphorus limitation (Güswell et al., 2003). The N:P ratios found in Ewen Maddock Dam (20.6) and Seibs Dam (18.1) were higher or close to the suggested threshold of 20 . This means that $C$. caroliniana might be limited by phosphorus in these systems, corroborating the findings from the regression analysis.

This study indicates that in warm subtropical areas C. caroliniana growth patterns are more likely regulated by local habitat variables than seasonal conditions. Therefore, future spread of this plant will be more restricted by habitat conditions than climatic aspects. Currently we do not know if the depth limitation of $C$. caroliniana that was found here was solely due to light attenuation and physical stress or other environmental variables. We expect that $\mathrm{pH}$ will be 
one of the most important factors determining $C$. caroliniana spread. As C. caroliniana does not tolerate $\mathrm{pH}>7.5$ (Bickel, 2012Bickel, 2012 Mackey and Swarbrick, 1997; Ørgaard, 1991), establishment will be primarily determined by the $\mathrm{pH}$ of the recipient water. Apart from abiotic factors, human transport of fragments will largely determine the future spread of this species in Australia (Bickel, 2015). C. caroliniana rarely produces viable seeds in its introduced range and therefore depends primarily on humans to disperse vegetative propagules to new watersheds.

\section{Acknowledgements}

P. Moran, A. Petroeschevsky, R. Rainbird, B. McMullen, P. Clifton, C. and K. Seibs, Noosa Shire Council, Noosa Landcare, and the Lake Macdonald Catchment Care Group provided information and support. Special thanks to M. Julien and T. Anderson for their lead roles in developing this project. A big thank you to M. Stewart, SEQwater, for providing water quality data for Ewen Maddock Dam and Lake Macdonald. Thanks also to DEH and a number of stakeholder groups for contributing funding.

\section{References}

Anderson, T., Diatloff, G., 1999. Cabomba management attempts in Queensland. In: 10th Biennial Noxious Weeds Conference, 'practical Weed Management: Protecting Agriculture and the Environment', Ballina, Australia.

Bickel, T.O., 2015. A boat hitchhiker's guide to survival: Cabomba caroliniana desiccation resistance and survival ability. Hydrobiologia 746, 123-134.

Bornette, G., Puijalon, S., 2011. Response of aquatic plants to abiotic factors: a review. Aquat. Sci. 73, 1-14.

Camargo, A.F.M., Pezzato, M.M., Henry-Silva, G.G., Assumpcao, A.M., 2006. Primary production of Utricularia foliosa L., Egeria densa Planchon and Cabomba furcata Schult and Schult.f from rivers of the coastal plain of the State of Sao Paulo, Brazil. Hydrobiologia 570, 35-39.

Duarte, C.M., 1992. Nutrient concentration of aquatic plants: patterns across species. Limnol. Oceanogr. 37, 882-889.

Dugdale, T.M., Butler, K.L., Clements, D., Hunt, T.D., 2013. Survival of cabomba (Cabomba caroliniana) during lake drawdown within mounds of stranded vegetation. Lake Reservoir Manage. 29, 61-67.

Ensby, R., 2004. Cabomba. DPI, NSW.

Güswell, S., Koerselman, W., Verhoeven, J.T.A., 2003. Biomass N:P ratios as indicators o nutrient limitation for plant populations in wetlands. Ecol. Appl. $13,372-384$.

Güswell, S., Koerselman, W., 2002. Variation in nitrogen and phosphorus concentrations of wetland plants. Perspect. Plant Ecol. Evol. Syst. 5, 37-61.

Hawes, I., Riis, T., Sutherland, D., Flanagan, M., 2003. Physical constraints to aquatic plant growth in New Zealand lakes. J. Aquat. Plant Manage. 41, 44-52.

Hogsden, K.L., Sager, E.P.S., Hutchinson, T.C., 2007. The impacts of the non-native macrophyte Cabomba caroliniana on littoral biota of Kasshabog Lake, Ontario. J. Great Lakes Res. 33, 497-504.

James, C.S., Eaton, J.W., Hardwick, K., 2006. Responses of three invasive aquatic macrophytes to nutrient enrichment do not explain their observed field displacements. Aquat. Bot. 84, 347-353.
Les, D., Mehrhoff, L., 1999. Introduction of nonindigenous aquatic vascular plants in southern new england: a historical perspective. Biol. Invasions 1, 281-300.

Lyon, J., Eastman, T., 2006. Macrophyte species assemblages and distribution in a shallow Eutrophic Lake. Northeast. Nat. 13, 443-453.

Mackey, A.P., 1996. Cabomba (Cabomba spp.) in Queensland - Pest status review series - Land Protection Branch. Land Protection, Department of Natural Resources and Mines, Coorparoo, QLD, 36 p.

Mackey, A.P., Swarbrick, J.T., 1997. The biology of Australian weeds 32. Cabomba caroliniana Gray. Plant Prot. Q. 12, 154-165.

Madsen, T.V., Cedergreen, N., 2002. Sources of nutrients to rooted submerged macrophytes growing in a nutrient-rich stream. Freshwater Biol. 47, 283-291.

Matthews, J., Beringen, R., Lamers, L.P.M., Odé, B., Pot, R., van der Velde, G., van Valkenburg, J.L.C.H., Verbrugge, L.N.H., Leuven, R.S.E.W., 2013. Knowledge document for risk analysis of the non-native Fanwort (Cabomba caroliniana) in the Netherlands. Radboud University Nijmegen, Institute for Water and Wetland Research, FLORON \& Roelf Pot Research and Consultancy, Nijmegen, the Netherlands, $60 \mathrm{p}$.

Noel, J., 2005. Growth, Reproduction and Control of an Invasive Aquatic Plant, Cabomba Caroliniana, in Kasshabog Lake, Ontario and Its Potential Dispersal. Trent University, Peterborough, Ontario, 89 p.

O'Hare, M.T., Clarke, R.T., Bowes, M.J., Cailes, C., Henville, P., Bissett, N., McGahey, C., Neal, M., 2010. Eutrophication impacts on a river macrophyte. Aquat. Bot. 92, 173-178.

Oki, Y., 1992. Integrated management of aquatic weeds in Japan: current status and prospect for improvement. Biological control and integrated management of paddy and aquatic weeds in Asia, Tsukuba, Japan, pp. 197-213.

Ørgaard, M., 1991. The genus Cabomba (Cabombaceae)-a taxonomic study. Nord. J. Bot. 11, 179-203.

Core Team, R., 2013. R: A Language and Environment for Statistical Computing. R Foundation for Statistical Computing, Vienna, Austria http://www.R-project.org

Riemer, D.N., Ilnicki, R.D., 1968. Reproduction and overwintering of Cabomba in New Jersey. Weed Sci. 16, 101-102.

Sand-Jensen, K., 1989. Environmental variables and their effect on photosynthesis of aquatic plant communities. Aquat. Bot. 34, 5-25.

Schooler, S., Cabrera-Walsh, G., Julien, M., 2012. Cabomba caroliniana Gray (Cabombaceae) M. Julien. In: McFayden, R., Cullen, J. (Eds.), Biological Control of Weeds in Australia. Csiro Publishing Collingwood, Victoria, pp. 108-117.

Schooler, S., Julien, M.H., 2006. Effects of depth and season on the population dynamics of Cabomba caroliniana in south-east Queensland. In: Proceedings of the 15th Australian Weeds Conference, Adelaide, Australia.

Schooler, S.S., 2008. Shade as a management tool for the invasive submerged macrophyte, Cabomba caroliniana. J. Aquat. Plant Manage. 46, 168-171.

Sharip, Z., Schooler, S.S., Hipsey, M.R., Hobbs, R.J., 2012. Eutrophication, agriculture and water level control shift aquatic plant communities from floating-leaved to submerged macrophytes in Lake Chini, Malaysia. Biol. Invasions 14, 1029-1044.

Sheldon, S.P., 1994. Invasions and declines of submersed macrophytes in New England: with particular reference to Vermont lakes and herbivorous invertebrates in New England. Lake Reservoir Manage. 10, 13-17.

van Valkenburg, J.L.C.H., Roijackers, R.M.M., Leonard, R., 2011. Cabomba Caroliniana Gray in the Netherlands. In: 3rd International Symposium on Weeds and Invasive Plants, Ascona, Switzerland, p. 6.

Wersal, R., Madsen, J., 2011. Influences of water column nutrient loading on growth characteristics of the invasive aquatic macrophyte Myriophyllum aquaticum (Vell.) Verdc. Hydrobiologia 665, 93-105.

Wilson, C.E., Darbyshire, S.J., Jones, R., 2007. The biology of invasive alien plants in Canada. 7. Cabomba caroliniana A. Gray. Can. J. Plant Sci. 87, 615-638.

Zhang, X.Y., Zhong, Y., Chen, J.K., 2003. Fanwort in Eastern China: an invasive aquatic plant and potential ecological consequences. Ambio 32,158-159. 